\title{
Punane regilaulus: sõnad ja vormelid ${ }^{1}$
}

Tiiu Jaago

\begin{abstract}
Teesid: Artiklis vaadeldakse värvinime "punane" esinemist Tartu- ja Läänemaa regilauludes. Varasemad uurimused regilaulu värvinimede alalt osutavad sellele, et kuigi värvinimesid kohtab lauludes harva, esinevad need silmahakkavalt väljakujunenud sõnaseostes. Võttes aluseks vormelikäsitluse (s.o eelduse, et värvinimed, sh "punane", esinevad regilauludes püsivates leksikaalsetes seostes) ja lähtudes kontekstikesksest folkloristikast (mille järgi püsivad sõnaseosed on tõlgendatavad üldisemas kontekstis, antud juhul motiivi ja teema tasandil) on analüüsitud "punase" ("puna", "verev") esinemisviise nii laulus esitatud sõnumite kui ka vormelite varieerumise vaatepunktist. Ilmneb, et kuigi värvinime sisaldavad vormelid varieeruvad sõnastustasandil, on nende temaatiline kasutuskontekst suhteliselt stabiilne.
\end{abstract}

Märksõnad: Läänemaa regilaul, punane, Tartumaa regilaul, vormel, värvinimed

Regilaulu värvigamma pakkus rohkelt aruteluainet 1970. aastate lõpul ja 1980. aastate alguses, tõustes veel kord esile 1990. aastate keskel. Sõnavõtud koondusid kas enam maailmapiltide ja sümbolite teemale või siis värvisõnade kultuuri- ja keele(aja)loolisele taustale (vt nt Sarv \& Sarv 1979; Parmasto 1982; Viires 1983; Roll 1985; Sarapik 1994, 1997). Et paremini eristada värvitaju, -sümboolika ja -nimetuste teemat, sekkus arutellu psühholoog Jüri Allik (1982). Keeleajaloolisest vaatepunktist pakkusid enam lisateavet Urmas Sutropi uurimused, sh eksperimentaalne töö, milles ta Brent Berlini ja Paul Kay esitatud teooriale tuginedes esitas eesti keele põhivärvinimede kujunemisjärgud (Sutrop 1995, 1996). ${ }^{2}$

Rahvaluuleteoreetilisest vaatepunktist rõhutati vajadust kvantitatiivsete uuringute järele, mis omakorda viisid vormeli-kontseptsiooni rakendamiseni värvisõnade analüüsis (Ernits \& Sarv \& Tedre jt 1981; Jaago 1997). ${ }^{3}$ Vormelikontseptsioonist on lähtutud ka käesoleva artikli regilaulude analüüsi-osas. 
Regilauluvärvide alased uuringud on omakorda pakkunud paralleelteavet arheoloogidele: nagu regilauludes, nii on ka keskaegse naise rõivastuses eelistatumad värvid sinine, punane ja valge (Rammo 2015). Mõistagi ei ole rõiva- ja regilauluvärvide vahel otseseost (ühel juhul on tegemist kanga värvimistehnikate ja rõivamoega, teisel juhul stereotüüpsete sõnaseoste ja regilaulu-omaste tähendusväljadega). Ometi viitab see üldisele kultuuripildile, kus teatud värvidel on suurem osakaal.

\section{Regilaulu värvisõnad - käsitluse üldtaust}

Regilaulu värvisõnade esinemissageduse vaatlused osutavad asjaolule, et regilaulus värvinimesid tihti ei kohta. Näiteks Kodavere 318 regilauluteksti põhjal koostatud sõnasagedusloendis ei leidu 50 enamlevinud sõnatüve ja sõnaseoste hulgas ühtki värvinime, v.a "kuld”, mis võib teatud määral olla mõistetud värvinimena (Saarlo 2001: 273, 295-297). Eesti rahvalaulude antoloogia I köite 1. vihu 772 laulust esineb värvinimesid 175 laulus, s.o 22,6\% tekstidest (Jaago 1997: 54). Samas viitavad värvisõnade sagedustabelid sellele, et teatud värvisõnu kasutatakse teistest enam. Näiteks eelmainitud rahvalaulude antoloogia I: 1 põhjal koostatud värvisõnade nimestikus esineb kõige enam "punast" (73 korda), seejärel on "sinine", "hall" ja "must" (55 korda) ja "valge" (44 korda). Hoopis vähe esineb aga "rohelist" (5 korda) ja "kollast" (2 korda). Kui ühitada need andmed teadmistega eesti keele põhivärvinimede kujunemisetappidest (vt Sutrop 1996: 662), võib näha teatavat kattumist. Lihtsustatult võib öelda, et regilauludes enamlevinud värvinimed on keeles ka varem välja kujunenud. Kuid öeldut ei saa taandada pelgalt eesti keele värvinimede kujunemise ajaloole: seda ei keeleajaloolisest ega ka regilauluteoreetilisest vaatepunktist. Kui jätta hetkel kõrvale asjaolu, et regilauludes kasutatakse murde-, mitte kirjakeelt, seisneb probleem selles, et põhivärvinimed võivad erinevatel keeleajaloolistel etappidel muutuda. Näiteks regilaulus sageliesineval sõnatüvel "puna" on suhteliselt pikk ajalugu: eesti keele etümoloogia sõnaraamatu järgi kuulub see soome-ugri perioodi. Samas värvinimetuseks kujunes see hiljem, läänemeresoome ajajärgul, tähistades varem mõistet "karv" (karva). Urmas Sutropi esitatud värvinimede kujunemisjärkude skeemilt võib punast värvi tähistavate sõnadena näha ka "koitu" ("koje) ja "verevat" ("wire) (Sutrop 1996: 663-667). Sutrop juhibki tähelepanu sellele, et "keele jõudmisel järgmisse arengujärku mitte ainult ei lisandu uusi värvide põhinimetusi, vaid et sageli vahetuvad ka olemasolevad põhinimed" (Sutrop 1996: 661). See seletab ka asjaolu, miks nt sõna "hall" on regilaulus palju kasutust leidnud, kuigi põhivärvinimeks 
on see kujunenud suhteliselt hiljuti - 18. sajandil, see on samal ajal sõnaga "pruun", mida regilaulus kohtab jällegi haruharva (vrd Jaago 1997: 55-57). Võib järeldada, et regilaulude värvisõnakasutus on samuti teinud läbi muutusi, mis vähemalt osalt on toimunud kooskõlas keeleajalooliste muutustega.

Folkloristlikust vaatepunktist regilaulu värvinimede esinemissagedust käsitledes on oluline arvestada seda, et regilaul koosneb pigem väljakujunenud sõnaseostest (vormelitest) kui vabalt kokkupandavatest üksiksõnadest. See tuleb esile ka värvisõnade puhul. Samuti ilmneb, et need värvinimed, mida regilaulus esineb teistest enam, kuuluvad samal ajal paljudesse stereotüüpsetesse ühenditesse. Tuues siinkohal vaid mõned näited "punase" erinevatest kasutusseostest, võib eristada kahte tasandit. Esmalt ühildumine värsitasandil algriimuvate sõnadena (alliteratsioonivormelid), näiteks "pale punane": "pahatsel pale punane", "eks ole pale punane", "löömata pale punane"). Teiseks värvisõnade seostumine paralleelsõnadena värsirühmas (parallelismivormelid), näiteks "sini / puna" esimeses alltoodud näites naise sünonüümidena ("sinisääri / punapõske") või "puna / valge" teises näites, viidates laulu minategelase töös ja külmas taanduvale tervisele:

Pärast tood naese Narva maalta, sini sääri Saksamaalta

puna põski Poolamaalta.

E 14319 (1) < Viljandi (a-ta).

Ju puna minust pugenud, ju valge minust vajunud.

Puna läinud puute peale

valge rehevarda peale.

H III 3, 459 (2) < Kose (1888).

Analoogilistes motiivides võivad värvinimed kombineeruda teiste omadussõnadega, moodustades kinnistunud sõnapaare nii värsi kui ka värsirühma tasandil, millest üks silmahakkavamaid seoseid kosjateemalistes, pulma- ja vaeslapselauludes on "pale punane / ihu ilusa":

Kas pole kõrki kõrvassagi?

Eks ole valge vastassagi.

Eks ole pale punane,

eks ole ihu ilusa,

eks ole mokad muodusamad.

H I 1, 89 (51) < Kadrina (1888). 
Võera armud, võera hirmud, need käivad läbi südame, läbi mu ihu ilusa, läbi mu pale punase, läbi mu halli uиe kuиe, läbi mu kauni kingakese.

H I 5, 513 (1) < Viljandi (1894).

Märkimisväärselt sageli ühilduvad paralleelsõnadena "punane / sinine", kusjuures need võivad teineteisele vastanduda (nagu esimeses alltoodud näites on "sinine" laulik nõrgem "punasest"), täiendada teineteist (nagu teises alltoodud tekstikatkes kujutluspilt pilvest, millest sai "punane hani" ja sellest omakorda "sinine saba", olgu see siis võib-olla ka metafoorsena tõlgendatav) või loovad need värvinimed koos mingi terviknähtuse (nagu alltoodud kolmandas näites silla siin- ja sealpoolsuse vahel):

Mis sina, sinine, laulad!

Las mina, punane, laulan.

EÜS VI 1115 (291) < Jõhvi (1909).

Pilvest saab vee pisara, pisarast sai pikka purju, purjust sai ani punane, anist sai saba sinine.

EÜS VI 1391/3 (46) < Koeru (1909).

Oo minu hella eidekene, viska maha, vinna köisa, lase maha laeva köisi, siruta sinine lónga, pueta punane lõnga, tõmba minda taeva'assa!

H I 5, 513 (1) < Viljandi (1894).

Kui tänapäeva ettekujutuste järgi on üks värvilisemaid nähtusi vikerkaar, siis näiteks Virve Sarapiku uurimustest selgub, et kuigi rahvausundi varasemates kihtides võib näha vikerkaare seostamist küll vee, maailmasid ühendava silla või kaarega, kohtab värve vikerkaarega ühenduses haruharva: "Tänapäeva inimese teadvusse kinnistunud vikerkaare seitset värvi ei kohta me aga kuigi sageli" (Sarapik 1993: 54). Põgusalgi vaatlusel selgub, et eelöeldu kehtib ka regilaulu kohta: "vikerkaar" koondub regilauludes kas looduskujunditesse, ebamaiste teekondade või kiidetud noormehe kirjeldustesse. Ootuspäraselt esineb 
"vikerkaar" algriimilistes seostes sõnadega "vesi", "vöö", "vend", "vihm" (noormehe kiituses on vöö kui vihma vikerkaar; vaeslapselaulus on taevas minu tare, vikerkaar mu vihmavari). Tavapärasest eristuv teekond viib läbi "viie vikerkaare":

\section{Alt mina aasin halli ilma, keskelt kuu kumera, vahelt viie vikerkaari, oma neidu otsidessa.}

H III 8, 366 (3) < Palamuse (1890).

Värvinimetusi vikerkaarega seoses regilauludes tavaliselt ei kohta. Ilmselt ei taandu see tõdemus pelgalt vikerkaare ja värvide seostamatusele iseenesest (ehk tänapäevasest erinevale kujutluspildile), vaid oma osa on regilaulu vormellikul keelel, mis seob sõnu värsis kõla kaudu ("vikerkaar" > "vesi", "vend", "vöö", "vilelööja”, "viie” jms). Ometi võib vikerkaart kui nähtust (mitte sõna) regilaulus seostada värvidega, nimelt taas "sinise" ja "punase" parallelismiseosega (Sarapik 1993: 54-55; Jaago 1997: 62-64).

Eelnevat kokku võttes võib tõdeda, et regilaulu värvigamma uurimise praeguses etapis on otstarbekas lähtuda vormelikeelest. Varasemad uurimused on andnud piisavalt teadmisi nii värvisõnade esinemissageduse kui ka värvisõnade abil kirjeldatavate nähtuste kohta, et öelda, milliseid leksikaalseid püsiühendeid ehk vormeleid (nagu eelpool "viie - vikerkaari") värvisõnadega ühenduses otsida võiks. Samas on vormelite kasutus küllalt varieeruv, mis ei võimalda ilma motiivi (teema, laulu tervikteksti) arvestamata nende kujundite semantilist välja määratleda. Näiteks "pale punane" esineb sageli laulutegelast kiitvas tähenduses, eriti, kui sellele liitub paralleelvärsis "ihu ilusa". Samas kasutatakse seda vormelit ka "tuima neiu" motiivis, kus laulikmina annab nõu seda tütarlast mitte kosida.

Tuimal turtsaku juusse, vihatsel silma vesitse, pahatsel pale punane.

H II 59, 779 (30) < Rõngu (1896).

Vormeli “pale punane" leksikaalne lähiümbrus (omadussõnad "tuim”, "vihane", "pahane") nihutab siin näites ilu ja tervist märkiva "punase" vihast või tigedusest esile tõusvale "punasele".

Rahvaluuleteoreetilisest vaatepunktist on intrigeeriv, et konteksti osa teksti tähenduse mõistmisel kehtib ka rahvaluule (teksti) seisukohast nii väikesel tasandil nagu seda on regilaulu vormel. Dan Ben-Amos on kontekstikeskse folkloristika põhimõttest lähtuvalt sõnastanud teksti ja tähenduse seose järg- 
miselt: "Kui tekst on kas temaatilisel, morfoloogilisel, struktuurilisel või metafoorsel tasandil stabiilne, kuid kontekst varieerub, põhjustab just viimane teksti poolt loodavaid tähenduserinevusi, järelikult toimib kontekst rahvaluuletekstide interpretandina" (Ben-Amos 2009a [originaalis esimest korda 1993]: 31). Mida lühem ja stabiilsem on tekst, seda suurem on selle sõltuvus kontekstist, lisab Ben-Amos samas. Analoogilisele seisukohale jõudis Ülo Tedre Karksi regilaulude stereotüüpsust analüüsides. Kuigi selleaegses regilauluteoorias (1960. aastate alguses) eeldati stabiilsust laulude tasandil, ${ }^{5}$ märkab Tedre esmalt, et terviklaul allub muutustele (improvisatsioonile) tunduvalt paindlikumalt kui üksikvärss, ja teiseks, et "stereotüüpne värss ei kanna laulu sisu”, mis võimaldab seda kasutada mitmetes tähendusseostes (vt Tedre 1964b: 84). Teisalt aga tekib kontekstikeskse folkloristika kui teoreetilise raami seisukohast ka teatav kitsaskoht: vormelite tõlgendajana on tänapäeva uurija väljaspool pärimuse valdajate tõlgendusruumi - lauljate ja tõlgendajate jaoks on sama teksti kontekstid erinevad (vrd Ben Amos 2009b [1971]: 21). Analüüsi seisukohast on seega vältimatu minna tagasi värvisõnade sagedustabelite juurde. See võimaldab rekonstrueerida laulukeelt (teisisõnu: aimata, mida tähendas, et laulikul on "palju sõnu"), et selle kaudu tõlgendada värvisõnu sisaldavaid vormeleid neid üksteisega suhtesse seades.

\section{Allikad ja teoreetilis-metoodiline raam}

Käesolevas artiklis käsitletakse värvisõna "punane" (võrdlevalt ka "puna", murdest tulenevalt lisandub "verev"). Et valik langes just sellele värvisõnale, tulenes sagedustabelitest, mis on näidanud selle värvisõna rohket kasutust. Ühtlasi on regilaulude senisest analüüsist selgunud, et "punasel" on mitmeid stereotüüpseid tähendusvälju. Võrreldud on kahe, regilaulutraditsiooni vaatepunktist erineva traditsioonipiirkonna laule: Läänemaalt 125 ja Tartumaalt 166 teksti. Tuginedes "Eesti regilaulude andmebaasile" (http:// www.folklore.ee/regilaul/andmebaas) on koostatud andmetabel, mis sisaldab nii värvinime koos selle leksikaalse ümbrusega kui ka laulutekstiga seotud kommentaare (arhiiviviide, sh laulu kirjapanemisega seotud teave, laulutüüp, funktsioon). Andmete selline kooslus on vajalik, kui analüüsida värvinimega seotud kujundeid eeldusel, et need seostuvad kindlate laulumotiivide ja -teemadega, moodustades seejuures vormeleid. Sama toimimisviis õigustas end ka nt regilaulu linnanimede uurimisel (Jaago 2013).

Analüüsi teoreetiliseks aluseks on valitud vormelikäsitlus (Kolk 1962, 1980; Harvilahti 1992; Saarlo 2000, 2001). Regilaulu vormelite uurimine sai alguse regilaulu stereotüüpia ja varieerumise uuringutest 1950.-1960. aastatel Udo 
Kolgi töödes. Nimelt eristas Udo Kolk stereotüüpse korduvuse väiksemal tasandil kui seda käsitleti tavaliselt (värss, värsirühm, lause vms), näidates, et väikseim ja samas universaalne element laulus on "värsisisene vormel" (Kolk 1962: 147). Kolgi töö lähtus ühe lauliku repertuaari süvaanalüüsist, mistõttu värsisiseste vormelite neli alaliiki (alliteratsioonilised sõnapaarid, meetrilised vormelid, stereotüüpsed sõnaühendid ja parallelismivormelid) avas ta näidete kaudu. Värvinimedega seotud vormeleid on Kolgi selles käsitluses kaks: alliteratsioonilise sõnaühendina "must muld" ja stereotüüpse sõnaühendina naise või pruudi metonüümne sünonüüm "sinipõll” (Kolk 1962: 90-91, 119). Hilisemas töös keskendus Kolk alliteratsiooni- ja parallelismivormelile, näidates vormelikontseptsiooni ühisosa teiste uurijate (Ülo Tedre, Veera Pino, Juhan Peegel) töödega, milles regilaulu praktilisele analüüsile tuginedes tegeldi samuti stereotüüpsete kordustega, kuigi vormeli mõistet neis töödes ei kasutatud (Kolk 1980: 27). Kolk selgitas vajadust regilauluvormelite registri koostamise järele, tuues ka sellekohase näite. Ta pakkus skeemi, mille keskme moodustab vormeli üks koostissõna (Kolgi näiteskeemil oli selleks "must") ja lisas sellele nii allitereeruvad kui paralleelsõnad (vastavalt "muld", "mure" jne ning "valge") (Kolk 1980: 35).

Vormeleid on seega eristatud esialgu kvalitatiivsete meetoditega, lugedes võrdlevalt laulutekste. Tekstianalüüsidest üha enam materjali kogudes on jõutud kvantitatiivsete meetodite rakendamiseni, mida hõlbustas ka arvutite levik ja sellega seotud uue tehnoloogia kasutuselevõtt uurimisprotsessis. Neist võimalustest lähtus Liina Saarlo, kes lokaaltraditsiooni (Kodavere) näitel analüüsis sõnade ja sõnaühendite statistilist korduvust regilauludes ning selle seost vormelikeelega (Saarlo 2001). Ühtlasi on Saarlo püstitanud küsimuse regilaulu sõnaühendite registri vastavusest muude tekstikorpuste (tavakeel, parömioloogilised üksused) põhjal koostatud registritele (Saarlo 2000: 147 jj). Paralleelselt eelkirjeldatud arengutega toimus 1980.-1990. aastatel teinegi muutus: laulu üksikosade fikseerimise asemel hakati üha enam tegelema tekstide tõlgendamisega lauluteemat, lokaaltraditsiooni vms kontekste arvestades (vt nt Harvilahti 1992: 88-90). Nende arengute põimumine toob kaasa kvalitatiivsete ja kvantitatiivsete uurimisviiside kombineerimise.

Kuidas praeguses teaduspildis siis piiritleda alliteratsioonilisi ja parallelismivormeleid? Üldjoontes on seda tehtud sõnaseoste kordumisi fikseerides. See tegevus võis rajaneda kas tekstide lugemisele või andmete masintöötlusele (andmete hulk ja iseloom on kummagi tegevuse puhul erinev). Kuid on ilmnenud, et lihtsalt sõnaseoste sagedusuuringud vormelite piiritlemisele ei vii. Näiteks sõna(tüve) sagedustabelitele tuginedes väidab Liina Saarlo: "Kõige produktiivsemad sõnaühendid kipuvad pahatihti olema puhtalt grammatiliselt või süntaktiliselt seotud sõnad ja abisõnad" (Saarlo 2001: 293). Seega on 
vormelite piiritlemiseks vaja arvestada ka sõnaseoste tähendusruume, mis omakorda eeldab kvalitatiivsete meetodite rakendamist. Ühtlasi osutab Saarlo tõigale, et laulikule ja uurijale avanevad vormelid erinevalt: ühel juhul loomisprintsiibina, teisel juhul n-ö tekstist äratundmisena (samas). Töö (suurte) materjalihulkadega ühelt poolt ja laulu üksikosade kontekstikeskne analüüs teiselt poolt on kujundanud mustri käesoleva uurimuse tarvis. Sellest tulenevalt põimuvad siinses artiklis ühelt poolt regilaulu varasem vormelikäsitlus ja teiselt poolt kontekstikeskse folkloristika põhimõtted: kui 1950.-1980. aastatel oli eesmärgiks vormelite registri koostamine, piirdudes vormelina määratletavate sõnaseostega, siis käesolevalt analüüsitakse vormeleid kui osa püsimotiividest ja -teemadest.

\section{Värvisõna kui kujund}

Mil määral kasutatakse värvinimesid mingi nähtuse visualiseerimiseks? Mil määral on tegemist metafoorse kirjeldusega? Mõistagi ei õigusta selline eristus end täiel määral, sest enamasti on need alad kattuvad. Näiteks alljärgnevas on "Loomise" imelinnu kirjeldus, mida värvid muudavad küll visuaalselt ettekujutatavaks, kuid sellises koosluses viitavad ka asjaolule, et tegemist on argi-ilmale vastanduva linnuga:

Mis sealt merest välja tuli?

Hallikirju linnukene,

hallikirju hambad suus,

punane pugualune,

kollane kõhualune,

sinine sabaalune.

Lendas meie koppelie [---]

H 2 II, 343 (469) < Karuse (1889).

Sellegipoolest võiks proovida eristada vastavat dominanti: kas pigem (või mil määral) visuaalsus või metafoorsus ja kuidas mõjutab seda dominanti värvisõna leksikaalne ümbrus.

Tekste esmapilgulgi vaadeldes tuleb esile see, et sama sõna ("punane”) ei paku alati sama visuaalset kujutluspilti: "punane pale”, "punane pael”, "punane peni", "punapäine pääsukene" võimaldavad näha punase erinevaid toone. Enamasti mõjutab üldpilti “punase” leksikaalne kontekst (näiteks moodustades parallelismivormeleid nagu "punane pale / ihu ilusa", "sinikirja linnukene / punapäine pääsuke”). See haakub mõneti Mari Uusküla ja Urmas Sutropi põhivärvinimede Läänemere äärse areaalsuse uuringuga, kus sedastatakse: “[---] 
igal keelel on oma kindel parim näide punase, sinise, rohelise, kollase ja kõigi teiste värvide jaoks" ehk: igal keelel on oma "värviruum"' (Uusküla \& Sutrop 2014: 680; vrd Uusküla 2008). Regilaulu värvipildis on vähemalt kolm erinevat punast: pruunikaspunane, mis seostub eriti looma karva või linnu sulestiku värviga; tulipunane, mis seostubki tule, või ka riideesemete värviga, ja roosakam värv, mida kohtab nt päikesetõusu või loojumise ajal. Ometi ei ole see ka laulude mõistmisel nii lihtne. Näiteks "punane" hobuse tähenduses võiks luua kujutuse pruunikaspunase karvaga hobusest. Kuid kui hobune on laulus "veripunane", ei saa tavalist situatsiooni endale kuidagi ette kujutada. Pigem viib see mõtted värssides öeldu ülekandelisele tähendusele: kuna erinevat värvi hobuste kirjeldused liituvad pulmamotiividega, punane hobune aga eriti kosjamotiividega, siis võiks järeldada, et neis motiivides viitabki "punane" pigem sotsiaalsele pöördepunktile (mida kosjad ja pulmad markeerivad) ja taotluseks ei ole visualiseerida tavalist hobust:

Minul vennal ilus halli,
ilus halli, kõrki kõrvi,
veri putkejas punane.
Ei ta hirnu heinusida,
ei ta karju kaerusida.
Ta ikka hirnub ehteeida,
karjub kangid valjuuida,
noortsub noorta neiukesta.

H II 17, 359/60 (56) < Vigala (1889).

Eeltoodud laulukatkes tuleb esile veel üks oluline aspekt, mis juhib tõlgendaja konkreetse pildi visandamisest üldistuse juurde. Tegemist ei ole pelgalt hobuse värvi nimetamisega või ka hobuste kirjeldamisega nende värvi kaudu. Tegelaseks on üks hobune, kes on "ilus hall", "kõrki kõrb" ja "veri putkejas punane". Nii ühilduvad argised kujutelmad (hobustega seonduv) metafoorsete vihjetega (noormehe valmisolek naisevõtuks). See tuleb ilmsiks motiivi tasandil, olles seeläbi ühtlasi nähtav ka sõnatasandil.

Esemetele lisandudes võiks "punane" luua visuaalseid pilte, kuid kujund võib osutuda hoopis metonüümiks. Näiteks "punapärga" ja "punapõlle" on naise (nooriku, neiu, naiseks võetava õe) poeetilised sünonüümid. Poeetilise sünonüümi mõiste pärineb Juhan Peeglilt. Selle alla koonduvad põhisõna mõistemahuga täielikult kattuvad paralleelsõnad, kusjuures regilaulust väljaspool need sünonüümsed seosed ei kehti, sest need kuuluvad erinevatesse mõistesfääridesse. Näiteks sünonüümid "neiu : kabu" ei ole käsitletavad poeetiliste sünonüümidena, kuna need kuuluvad samasse mõistesfääri. Küll võib aga regilaulus "neiu" sünonüümiks olla "hani", mis omakorda on mõeldamatu tavakeeles (vt Peegel 
1997 [1969]: 50-52). Poeetiliste sünonüümide mõistega seoses viitab Peegel Villem Grünthal-Ridala tööle, kus viimane kirjeldab neid kui “piltlikke kordussõnu" ja seob selle nähtuse muinasskandinaavia luule käsitlustes kasutatava kenningite mõistega (Peegel 1997 [1969]: 51). Siit omakorda nähtub poeetiliste sünonüümide seos vormelikäsitlusega: tegemist on püsivate leksikaalsete seostega. Poeetiliste sünonüümide erijoon vormeli suhtes seisneb aga selles, et poeetilise sünonüümi puhul kattuvad põhisõna ja sünonüüm alati: eeltoodud näitele tuginedes võib öelda, et "punapärga" ja "punapõlle" on regilaulus igal juhul neiu, noorik, naine. Samal ajal võib neid ühendeid "punane - pärg", "punane - põll” käsitleda vormelitena, kuid sel juhul ei ole võimalik ilma leksikaalse lähiümbruseta öelda, millest õieti on jutt (kas neiu enda või tõesti neiu pärjaga). Nagu allpool esitatud analüüsist nähtub, on tõsi, et need vormelid on leitavad püsivalt naisevõtuteemat käsitlevates motiivides, kuid mitte alati ei ole need neiu või naise poeetilised sünonüümid. Seega võib väita, et vormelitel ja poeetilistel sünonüümidel on ühisosa, kuid need mõisted ei kattu.

\section{Tartu- ja Läänemaa laulude analüüs}

Alustades vaatlust naise poeetilistest sünonüümidest "punapärga" ja "punapõlle" võiks küsida, kas neis sünonüümides lisab täiend "puna" ühtlasi ka mingeid hinnanguid laulutegelasele (nt viiteid tervisele, ilule vms)? Ilmneb, et need sünonüümid on pigem neutraalsed. Need on pigem teated. Näiteks naine jäi Narva teele, punapärga Pärnu teele $e^{6}$ ehk teisisõnu, noormehel jäi naine kosjateel leidmata. Küll aga võib märgata, et valdavalt on tegemist kosja- või pulmateemaliste motiividega. Kui kasutatakse parallelismivormelit "sinine / punane", tuleb kosjateema rõhutatult esile.

Pojakene, poisikene!

Kui lääd naista võttemaie,

sinitaime tahtemaie,

punapärga püidemaie.

H II 33, 586 (6) Kursi (1889).

Läänemaa (pulma)lauludes on kohati "sini / puna" parallelismivormel asendunud vormeliga "siidi / puna", mis viitab laulutraditsiooni siirdevormilistele muutustele (vt nt Rüütel 1969: 109)7 :

Kaitse mu õde kalliesti,

siidirinda sirgeesti,

punapõlle puhtaesti.

E 64250/1 (19) < Hanila (1925). ${ }^{8}$ 
Ilmselt on haruldane ka ühes Sangaste laulus esinev "punase” paralleelsõnana kasutatav "roheline", kus mõlemad on neiu poeetilised sünonüümid (H III 10, 588 (3) < Sangaste (1889)).

Juhan Peegli koostatud poeetiliste sünonüümide sõnastikus pruuti (miniat, kosilase ootamiseks sirgunud neidu) tähistavate sünonüümide hulgas ongi vaid kolm värvinime: valge (nt "valgepea”), puna- ("punapärg”, "punapael”, "punapalg”, "punapõsk”, "punapõll”) ja sini- ("sinirind”, "sinilint”, "sinipill”) (Peegel 2004). Neist "valge" ja "punane" paralleelsõnadena on üsna sageli esinevad ja mitmeti varieeruvad, kuid enamasti on tegemist tegelase (peamiselt pruudi või peiu) kiitusega. Üks tuntumaid kiitusvärsse seostub "valgem vahust" motiiviga:

Küll on meres vahtu valge,

veel on valgem meie neidu.

Küll on meres kõrgid [kõrkjad] pikad,

veel on kõrgim meie neidu.

Pujuks põllal punane,

veel on punasem meie neidu.

H III 30, $302<$ Hanila (1902). ${ }^{9}$

Neiu sünonüümina ei ole "punapärga" nii üldlevinud kui võiks eeldada - Läänemaa lauludes seda polegi. Küll võib aga sama vormelit ("punane - pärg” koos paralleelsõnaga "valge") kohata kiigelaulude neiu kirjelduses: neiud lubavad heale kiigutajale andeid ja muuhulgas ka neiu, kellel on "pea valge, pärg punane":

Kes mind kõrges' kiigutab, sellel hea hinna annan, parajaste palga maksan, rehalt ma annan riimu härja [---]

vallast valge neiukese,

pea valge, pärg punane,

süsi mustad silma kulmud.

EKS 50, 18/21 (16) < Vigala (1885/86), vrd EKS 50, $94(75)<$ Vigala (1985/86).

Kolmanda värvinime ("must") lisandumine "valgele" ja "punasele", nagu eeltoodud näites, ei ole küll tavaline, kuid analoogiat võib siiski leida. Esmalt näiteks kolme värvi sisaldavate parallelismivormelite olemasolus, nagu "sinine / punane / kollane (või valge)" loomismotiivis ja kolme laeva kirjelduses. Teiseks võib leida samalaadset vormelikasutust ("punane / must") teistegi motiivide juures, näiteks "punasele" lisandub "musta silmakulmu" "tuima neiu" motiivis ("pahatsel pale punane, / kurjal musta silmakulmu"10). Ent sel juhul puudub 
paralleelsõnade hulgast enamasti "valge", mis "punase" ja "mustaga" koos muudaks tegelase positiivseks.

Nagu vormel "punane - pärg", nii ka "punane - põlle" ei ole sugugi alati naise poeetiliseks sünonüümiks, vaid seda leidub ka otsetähenduses noormehe kingitusena pruudile. Näiteks Tartumaa lauludes lubab kosilane pruudile tuua kingituste hulgas ka "puna põlle"11; laulikmina hoiatab noormeest, et ta ei kosiks neidu mõisast, kellel on "põll punane", mille on talle juba "poepoisid" toonud ${ }^{12}$; Läänemaal lubab noormees "petisest peiu" motiivis neiule tuua ehtedriided (rinda preesi, kaelakee, pitsmütsi, sitsikleidi ja punapõlle ${ }^{13}$ ), mis on taas viide pulmadele, ent noormees neis lauludes ei täitnud oma lubadust - pulmi ei tulnud. Lisaks esineb see vormel Tartumaa lauludes kingituse metafooris halva mehe kirjelduses: ilmneb, et piits või rusikas on lubatud punane põlle. ${ }^{14}$

Kui "punapärga" ja "punapõlle" neiu või naise poeetilise sünonüümina kosjaja pulmamotiivides on selliselt nimetatud naisetegelase suhtes neutraalsed väljendid, siis vormel "pale punane" esineb nimelt hinnanguid andvates motiivides. Hinnangulisus saavutatakse paralleelsõnadega ("pale punane / ihu ilusa" - ilus / punane) või ka täiendusega ("pahatsel pale punane" - pahasel). "Pahatsel pale punane" on püsiv ühend rohkem või vähem varieeruvas "tuima neiu" motiivis, mida esines 12 Tartumaa laulutekstis:

Mina tunnen tuima näiu:

tuimal turtsaku juusse, vihatsel silma vesitse,

pahatsel pale punane,

kurjal musta silmakulmu [---].

H II 59, 779 (30) < Rõngu (1896). ${ }^{15}$

Enamikul juhtudest, nagu eeltoodud näiteski, kuulub selle motiivi värvinimede hulka veel "must" ("kurjal musta silmakulmu”). Sama kohtab ka lauludes, kus "punase" asemel (või ka sellega koos) on sõna "verevä" ("kurjal musta silmäkolmu, / vihatseel silmä verevä"16). Vaid ühes lauluvariandis puudub värss "musta silmakulmu“. ${ }^{17}$ Kusjuures tavatu on ka selle laulu negatiivse naistegelase sünonüüm "valge". Üldjuhul viitab "valge" positiivsele tegelasele.

Heakskiidetud naise kirjeldustesse sobituvad täiendid "valge", "ilus", "priske", "punane", mis esinevad kas paarikaupa või pikemates kombinatsioonides. Nii Tartumaa kui ka Läänemaa lauludes lausub minategelane: võtsin naise noore, küll sai priske ja punane; või võttis ta valge neiu, kes oli priske ja punane; või kes oli valge ja punane. ${ }^{18}$ Neid naise värvikirjeldusi kasutatakse meelepärase naise esitlemisel, veel enam aga vastanduses: noormees kosis naise, kes oli terve, kuid nüüd on ta tõbine ("tõbise naise" motiiv). 
Üks parallelismivormeleid on "ihu ilusa / pale punane", mida võib taas kohata pulmalauludes peiu või neiu kiituses ${ }^{19}$ kuid mitte ainult. Seda võib üksikult leida Maarja ja Jeesuse kirjelduses, ${ }^{20}$ vaeslapselauludes, kus võõra armud käivad läbi vaeslapse ihu ilusa ja läbi ta pale punase. ${ }^{21}$ Sellest üks osa, alliteratsioonivormel "pale punane", seostub minategelasest neiu enesekirjeldusega, kus laulikmina punane pale paistab kiigelt kaugele. ${ }^{22}$ Teine sama vormeli kasutusseos viitab peksujälgedele (või ka, et ilma peksutagi on neiu pale punane):

Ärge lööge vaesta lasta, vaene nuttab löömata,

ikkeb ilma asjata.

\section{Löömata pale punane,}

pesemata silmad märjad.

E 18578 (7) < Maarja-Magdaleena (1895). ${ }^{23}$

Harva, ent siiski märgatavalt kasutatakse ka eelkirjeldatud parallelismivormeli "ihu ilusa / pale punane" lühikombinatsiooni "ihu punane". Seda kohtab ühes Tartumaa ja kuues Läänemaa mardilaulus, kus martidel on külmast "ihu punane". ${ }^{24}$ Vormel, "ihu punane" leidub ka ühe Tartumaa laulu laisa neiu kirjelduses. $^{25}$

Vaeslapse ja "Tütar vette" lauludes tähendab "punane" minategelasest kõrvaleheidetu ennast-turgutavat vastandust teistele: olgugi, et tema on jäetud ilma ema hoolest või kodutoest ning tema sööb putki põõsa alt, lakub vetta lainetesta, on ta siiski putkesta punane, vesinaadist vereva. ${ }^{26}$ Kuid niisamuti on "punane" kodus kasvanud neiu. Näiteks Tartumaa pulmalaulus kirjeldab minategelasest neiu isakodus kasvamise aega, kui ta oli oma kodus, kasvas oma kambris, oma akende all, punane. ${ }^{27}$ "Punane" võib olla "proua", kuna vald ja kihelkond tema eest töötavad. ${ }^{28}$ Kõik eeltoodud näited "punase" kasutamisest "ihu" või "palega" seotud kujundites viitavad motiivist sõltuvalt kas tervisele ja noorusele või külmast, pahameelest, löömisest lähtunud ärritusele.

Nii Tartu- kui ka Läänemaa lauludes tuleb esile kaks parallelismivormelit: "valge / punane", eriti mitmekesiselt aga "sinine / punane", millele võib liituda kolmas värvisõna (kollane, valge vms). Esimesel juhul on tegemist neiu kiitusega, olgu siis pulmalaulus või laulikmina enda noorpõlve enesekirjelduses. ${ }^{29}$ Teise parallelismivormeli puhul on tegemist mitmete iseseisvate motiivide koostisosaga. Üldlevinumaid neist on loomisloo lokaalredaktsioonid, kus nii peategelasest imelinnu kui ka tema valitud pesapaiga - põõsa - kirjeldustes kasutatakse värvinimedega paralleelsõnu. Siinses valimis esineb seda siiski vaid Läänemaa 14 laulutekstis. Tartumaal ei ole müütiline loomine laulude teemaks (Eesti rahvalaulud 1926: 70-71). Küll aga esinevad mõlemas regioonis mõned variandid "pilves veepisarate" motiivist, mis seostub kosjateemaga: 
Pilvel oli purje pikka, purjel oli ani punane, anil oli saba sinine.

H II 43, 808/9 (40) < Äksi (1893). ${ }^{30}$

Tartumaa lauludes esineb "sinise / punase" vormeli kasutamist sõjalaulumotiivis, kus sõjamehe ees on tuli punane ja taga on suitsu sinine. ${ }^{31}$ Läänemaa lauludes võib see vormel sattuda aga pulmalaulu ilmakirjeldusse, kus eilne ilm oli ilus ja taevas oli tasane, nüüd aga mitmekarvaline ja nelja-viie-viisiline: põhja alt õige punane, lõuna poolt sinine. ${ }^{32}$ Kui paari eelmist motiivi (pilvede ja ilma kirjeldust) saab piirioludega seostada kaudselt (need motiivid haakuvad viitega sotsiaalsetele muutustele neiu ja noormehe elus ja ühtlasi kogukonnas), siis otseselt kujutavad need seost siin- ja sealpoolsuse vahel Läänemaa mardilaulude teekonnakirjelduste ${ }^{33}$ ja Tartumaa vaeslapselaulus:

Minu hella emakene, siruta see sinine lõnga, poeta punane paella, tõmba minu taevasse.

E 711177 (16) < Rõngu (1895).

"Sinise / punase" vormeliga (millele võib lisanduda kolmas värvinimi: kas "valge", "kollane", "hall" või ka "kuldne") seostuvad seega loomisloo motiivid, kosja- ja pulmateema, lahinguväli sõjateemalises laulus, siin- ja sealpoolsust ühendav sild - kõik need haakuvad erilise olukorra kirjeldamisega ja on seejuures sõnastuselt väljakujunenud motiivid. Küllalt püsivas seoses kohtab sama parallelismivormelit veel võistulaulmisel laulikutele antavas hinnangus (seda eriti ohtralt Tartumaa lauludes):

Mis laulad, sina, sinine,

las laulda mina, punane.

E $33078(2)<$ Hanila (1897). ${ }^{34}$

Paaris Läänemaa laulus kirjeldatakse head kubjast, kes lööb töötegijaid niidist piitsa ja ôlekõrrest varrega, et siis kohe karata katsuma, kui tugevad on löögi jäljed:

Kas o sündinud sinine või o puutund punane.

E A $20(3)<$ Vigala $(1889){ }^{35}$

Nii Tartu- kui Läänemaa lauludes on üsna levinud sõnaseos "õlu(t) punane". Tartumaa lauludes, kus “õlu” paralleelsõnaks on "viin”, muutuvad ka vormelid: "viinasta (veesta) verevä / õllesta ilusa": 


\section{Muи om viinasta verevä muи om ôllesta ilusa.}

Mina ole ikusta ilusa, silmaviista verevä.

H III 21, 834 (7) < Otepää (1895).

Selles näites tuleb esile ka teine erinevus: kui üldiselt moodustab vormeli "õlu - punane" lauseehituslikult seotud sõnad - alussõna ja täiend, siis eeltoodud näites vormeliks olevad sõnad ("viina - verevä") ei ühildu omavahel lauseehituslikult, sest "vereväd" on teised ("muud"), mitte "viin".

Üldiselt esineb "verevä" samalaadses tähenduses "punasega" - see viitab kas rohkem tervisele või ilule (veli võttis verevä naase, jättis mulle musta naase ${ }^{36}$ ), kuid noormehe puhul seostub see halva mehe endega (ilus mees on ihusööja, verev mees verejooja ${ }^{37}$ ). Teisalt on aga pulmalaulude peiu kiituses või kadunud peiu (venna) otsimise lugudes, kus kasutatakse võrdlustele ülesehitatud pilti, "verev" peig igal juhul kiidetud..$^{38}$ Need võrdlusepisoodid sarnanevad "valgem vahust" motiivile, ent neis ei liitu "verevale" mitte "valge", vaid "ilus". Ülejäänud omadussõnad ("kõrge", "sirge", "terav" jms) on varieeruvamad. Iseloomulik aga on, et eriti verevä-ühendite puhul ei ühildu vormeliks olevad sõnad lauseehituslikult (nt värsis "verevide lille veeren" on vormeliseos sõnade "verev - veeren" vahel, täiendi ja põhisõna seostes on aga "verev lill"; analoogiliselt vormel "verev - veri" värsis, kus "verev mees [on] vere juuja").

Mõlema regiooni lauludes kohtab "punast" sageli nii kariloomade kui ka hobuste kirjeldustes. Esimesel juhul siiski enamasti looma kirjeldustes, teisel juhul pigem viitega kosjadele. Taas võib Tartumaa lauludes esineda samas positsioonis "verev".

Tartu- ja Läänemaa laule võrreldes ilmneb, et värvinime "punane" (puna-, verev) sisaldavad vormelid moodustuvad nii algriimiseostes ("pale", "põsk", "pere", "proua", "peiupoiss" jms) kui ka liitumisel laulumotiivi kesksete tegelaste või esemete kirjeldustega ("õun”, “õlu”, "kari” jms). Ilmneb ka, et leksikaalselt samade sõnaseoste ühisosa on napp. Esilekerkivamad on "pale punane", mida aga kasutatakse kummagi piirkonna lauludes erinevates motiivides ja "õlu punane", mille kasutuskontekst on silmapaistvalt mitmekesine. Mõlemas regioonis tuleb noore ja terve naise kirjeldustes esile ühend "priske ja punane", üksikuna ka vormelid "ihu punane", "marjamaa [on] punane". Kui mitte arvestada sõnajärge vormelis (s.o nii "põlle punane" kui "punane põlle"), lisanduvad "punasega" seotud ühenditena mõlema regiooni laulude ühisossa "pael", "põll" ja ka loomade nimetused. Hoopis sarnasemana võib mõlema regiooni repertuaari tajuda, kui vaadelda "punase" kasutusseoseid mitte värsi, vaid parallelismitasandil. Silmahakkavalt sageli kohtab värviseoseid "valge / punane"; "sinine / punane"; "punane / must". Parallelismitasandilt on enam nähtav värvinime- 
de (sh "punase") tähendusväli: need kas loovad vastandusi (nagu laulikute kirjelduses nõrk "sinine" ja tugev "punane" laulik, naise kirjelduses terve ja noor "punane" ning tõbine või taunitav "must" naine") või täiendavad üksteist (nagu "valge" ja "punane" koos on üldjuhul tegelast kiitvas motiivis, "sinine" ja "punane" kas sotsiaalseid või looduspiire markeerivates motiivides). Seega: vaadeldud regioonide "punase" ühisosa esineb pigem teemade ja motiivide kui kindlate sõnaseoste tasandil.

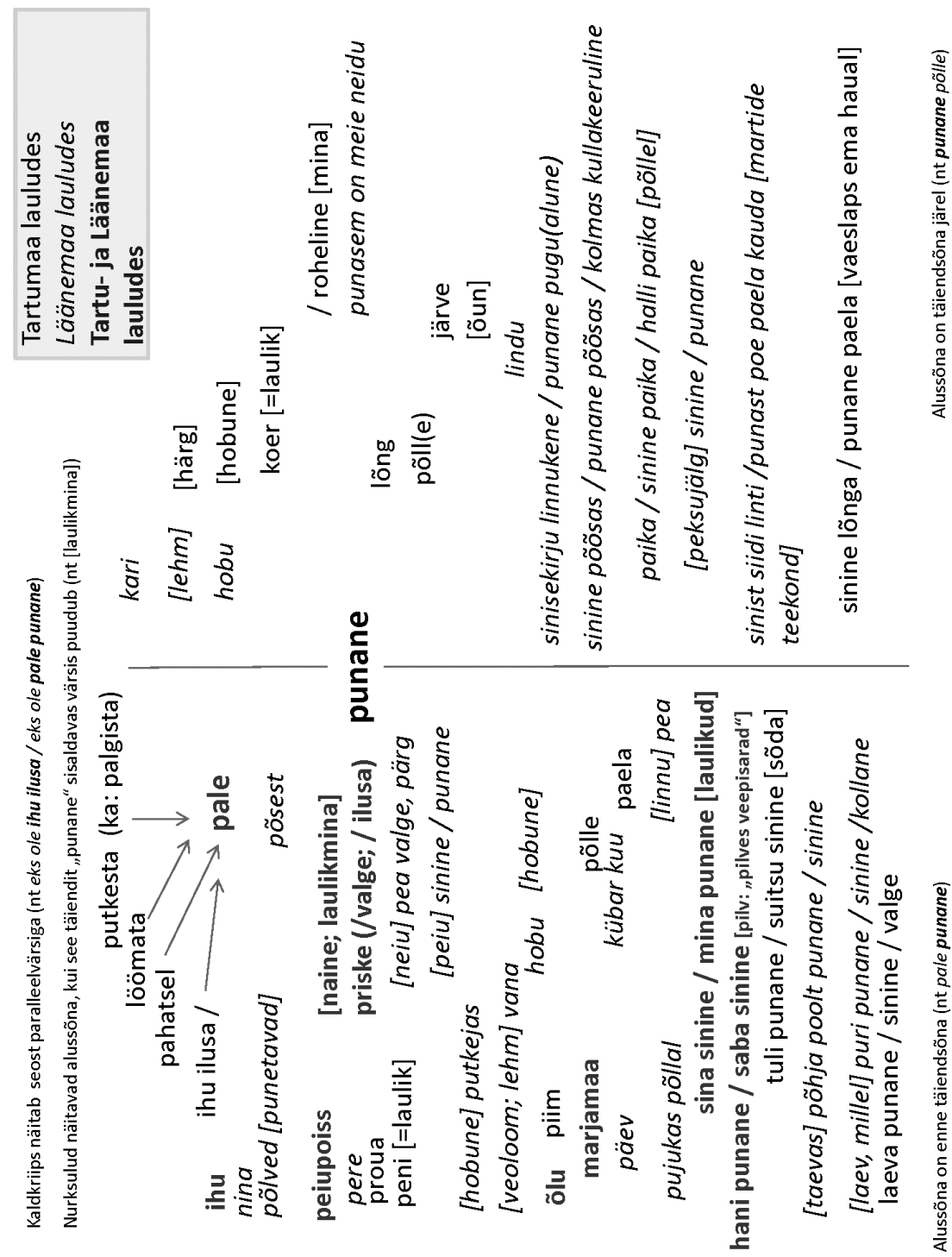

Skeem 1. "Punasega" seotud sõnad Tartumaa ja Läänemaa regilauludes. ${ }^{39}$ 


\section{Vormelite korduvus ja varieerumine}

Punase-vormelite arvukus tuleneb esmalt sama motiivi kordumisest (nagu nt "tuima neiu" värss "pahatsel pale punane" Tartumaal või loomisloo kolme põõsa motiiv Läänemaal). Teiseks - sama vormeli (varieeritud) kordumine teatud olukordade kirjeldamisel (nt "sinine / punane" sotsiaalse muutuse, loodusliku või siin- ja sealpoolsuse piiri kujutamisel). Viimasel juhul on värvisõnavormelite leksikaalne lähiümbrus küllalt mitmekesine. Sellest mitmekesisusest eristuvad teatud motiiviga haakuvad kujutluspildid-sõnaseosed. Pulmalaulu ilmakirjelduses (mida esines ainult Läänemaal) on taevas põhja poolt punane, lõuna poolt sinine; ja loomisloos on kolm põõsast: sinine, punane ja kullakarvaline. Olulised (ja regilaulu vormelikeelele omaselt) on nii sõnajärg kui ka kolmanda värvisõna lisandumine - need ei ole juhuslikud ja seostuvad taas kindlate motiividega. Läänemaa loomisloo ilmalinnu kirjeldustes aga sellist vormeliks kujunenud sõnastust ei ole: hoolimata sellest, et värvinimed "punane", "sinine", "hall", "kollane" ja "kirju" on püsivad, kasutatakse neid ebajärjekindlalt. Nii Tartu- kui ka Läänemaal esineva "pilves veepisarate" motiivi pilvest moodustub punane hani, kellel on saba sinine. "Kolme laeva" motiivis (nt "Venna otsija" laulus) on taas kolme värvi vormeli sõnajärg punane, sinine, kollane (valge). Pulmalauludes on üldjuhul laulikute dialoogis sinine nõrgem ja punane tugevam laulik. Seevastu inimeste (pruudi või naise, noormehe) kirjeldustes sõnapaaris "sinine" ja "punane" täiendavad teineteist (ikka ta seisab, sinine, ikka paigiti punane ${ }^{40}$ ). Sama kehtib ka peksujälgede kirjelduses (kas on sündinud sinine või on puutunud punane) ja sõjavälja kujutamisel, kus ees on tuli punane, taga suitsu sinine. Igal juhul on aga sõnajärg neis kujundites püsiv. Kõrvalekalle sellest võib tuleneda vormelite kombineerumisest, nagu alljärgnevas Läänemaa pulmalaulus: "ilus / punane" > "punane / sinine":

Aomies ilusikeline,

pane peale punane paika,

pane sisse sinine paika,

ääre pieal aja alli paika.

H II 2, 212 (319) < Karuse (1889).

Tõenäoliselt on samas tegemist ka regilaulutraditsiooni muutumisetapiga, kus vormelikeele kui kujundi ühtsus hakkas taanduma (vrd uuemale laulustiilile üleminekuga seotud muutusi Rüütel 1971: 11, muutusi leksikaalse analoogia seaduse järgimisel: Peegel 1997 [1972]: 104, 116). Näiteks Tartumaa lauludes on ebajärjekindel "pilves veepisarate" värvijärg, samuti ei ole kuigi püsiv ka laulikute sõimu motiiv ("sina, sinine / mina, punane" asemel ainult "punane", mis võib märkida nii nõrka kui ka tugevat laulikut). ${ }^{41}$ 
Teine küllalt esiletulev parallelismiseos on "punane/valge". Vaadeldud Tartuja Läänemaa lauludes on see reeglina kosja- ja pulmateemaliste laulude naise kirjeldustes, kus väljavalitu on priske ja punane, valge ja valusa. (Vahelepõikeks võib lisada, et hobuse kirjeldustes võib kohata sama, ent "valge" asemel on siis Läänemaa lauludes "linalakk", Tartumaa lauludes vastavalt "hall / punane".) Pulmalauludes, aga üksikult ka Maarja ja Jeesuse või mõisarahva kirjelduses, liitub "punasega" sageli "ilus". Kui värvinimed on metafoorsed (nagu eeltoodud näites priske ja punane, valge ja valusa), siis eelistatavalt on sõnajärjes "punane" enne "valget". Kui aga kirjeldatakse välimust ja alusmõiste, mida värvisõna täpsustab, on samas värsis, on sõnajärg vastupidine (pea valge, pale punane).

\section{Kokkuvõtteks}

Artiklis keskenduti regilaulu "punasele" ("vereväle"), lähtudes vormelikontseptsioonist. Selle järgi vaadeldakse regilaulu sõnavara mitte üksikute sõnade vaid leksikaalselt kokkukuuluvate püsiseoste kaudu. Vormelite tõlgenduses on arvestatud nende esinemise konteksti: motiivi ja teemat. Kahe regiooni laulurepertuaari võrdlevast analüüsist nähtus, et kuigi "punane" esineb mõlemas piirkonnas eelistatavalt erinevates motiivides, on teemade, värvinime kasutusviiside ja tõlgenduse tasand kõikjal sama. Seega - kõik alljärgnev kehtib mõlema piirkonna laulude kohta.

Ilmnes, et "punane" esineb alati vormellikus seoses, olgu selleks siis kas alliteratsioonivormel ("pale punane", "punapõll”) või parallelismivormel ("sinine / punane", "valge / punane"). Juhuseoseid "punane" ei moodusta. Kuigi esialgu võiks ju pidada mõnda seost juhuseks, näiteks "punane nina"42, selgub täpsemal vaatlusel, et see on "tuima neiu" variant vormelist "punane pale".

Värvisõnaga vormelite kujundiline sõnum ei avane üksikuna, ilma vormeli leksikaalse lähiümbruseta. Ei ole võimalik öelda, millist hinnangut kannab näiteks täiend "punane" sellistes ühendites nagu "pale punane", "punane põõsas", "proua punane". Küll aga ilmneb, et need vormelid kannavad teatud tähendust motiivi tasandil: pulmalaulude peiu või neiu kiituses viitab "pale punane" tervisele ja noorusele, "tuima neiu" motiivis aga neiu vihasele olemusele. Tunnuslik on ka see, et "punane" kaldub olema seotud kosja- ja pulmateemaga. Kui "punase" paralleelsõna on "sinine", siis kujutatakse märkimisväärselt sageli piirisituatsiooni nii sotsiaalses keskkonnas kui looduses.

Vormelina kokkukuuluvad sõnad ei pea kattuma lauseehituslikult kokkukuuluvate sõnadega, näiteks täiend ja põhisõna (kuigi valdavalt see siiski nii on). Nii ei pea kõik "velled" olema "vereväd", kuigi alliteratsioonivormeli moodustavad nimelt need sõnad - "velle - verevä" (vrd "purjel oli hani punane" - 
vormel on "puri - punane", ent lauseehituslikult on "hani punane"). Vastupidise näite pakub vormel "õlut punane" - tegemist on täiendi ja põhisõna ühendiga, ent neid sõnu ei seo vormeliks algriim.

Vaatlusest järeldus, et "punase" värvinimega seotud vormelid seostuvad mitte niivõrd statistilise korduvuse, kuivõrd teatud motiivide ja teemadega. Neist tulemustest edasi liikudes oleks huvitav küsida, mil määral siin ilmnenu kehtib ka teiste värvinimede (ja teiste vormelite) kohta. Ja ka näiteks: mil määral need kehtivad soome vana rahvalaulu värvisõnade (või ka "punase" kasutuse) kohta. Omaette küsimus võiks olla, mil määral seostuvad regilaulu värvid lauljate argipäeva värvidega. Lõpetuseks meenutangi üht laulu ja riietega seotud küsimust, mis mulle esitati Tartumaa lasteaiaõpetajate koolitusel 2014. aasta detsembris, kus regilaulu värviteemaga esinesin ja mis õieti oligi tõukeks selle artikli kirjutamisele. Nimelt küsiti, kas rahvariideseelikute värvitriipudele vastab regilaulus mingi kindel värv. Riietuse värvid regilaulus teataval viisil muidugi kajastuvad ("valged käiksed", "punapõlle"), kuid esmapilgul ma otseseost ei näinud. Hiljem olen aga mõelnud kahele seosele: esmalt pulmavärv punane - nii on see riietes ja lauludes, teiseks aga nimelt vormelikaudne seos. Nagu regilaulus, nii ka rahvariide seelikutriipudes varieeriti stereotüüpseid elemente.

\section{Kommentaarid}

1 Artikli valmimist on toetanud Haridus- ja Teadusministeeriumi uurimisprojekt IUT 2-43 "Traditsioon, loovus ja ühiskond: vähemused ja alternatiivsed diskursused".

2 Urmas Sutropi töö aluseks olev Brent Berlini ja Paul Kay uurimus Basic Color Terms: Their Universality and Evolution (1969) võimaldab põhivärvinimede kujunemist vaadelda seitset etappi läbiva universaalse arenguskeemi kaudu (vt nt Sutrop 1996; Uusküla 2008: 14). Eksperimentaalse uurimise käigus näitas Sutrop, et tänapäeva eesti keeles on 11 põhivärvinime (valge, must, punane, kollane, roheline, sinine, pruun, hall, lilla, oranž ja roosa), vastates nii "täielikult Berlini-Kay arenguskeemi viimasele, seitsmendale staadiumile" (Sutrop 1995: 808). Põhivärvinimed eristuvad muudest värvinimedest nelja kriteeriumi poolest, sh peab värvinimi olema monolekseemne (mistõttu põhivärvinimedena ei saa kirjeldada paljusid värvinimesid regilaulus nagu nt "andis sukad suitsukarva, / kindad keriksekarva, / paelad paha ilma karva") ja neid ei kasutata vaid teatud nähtuste kirjeldamiseks (nt "hobuse" sünonüümina "kõrb", "paat" vms, regilaulus "ruuge": "rukkil ruuged juuksed"; "üks oli ruuge rukki välja").

3 Regilaulu keele vormellikust loomusest kirjutas tunnetuslikult Fr. Tuglas 1912. aastal ilmunud Noor-Eesti IV albumis essees "Kirjanduslik stiil". Ta osutab nii sellele, et laulus kasutatakse aegade jooksul väljakujunenud "lauluridu", "võrdlusi" ja "kõnekäände" (ehk siis tänapäeva mõistes vormeleid) kui ka sellele, et nende paljukordse kasutamise tõttu on need kaotanud oma "iseseisva mõtte" (s.t nende kasutusseos varieerub) (Tuglas 1912: 30-31). Vana rahvalaulu stereotüüpse väljenduse iseloomustamisel on väljakujunenud sõnaseostele tähelepanu juhitud jätkuvalt (vt ülevaadet 
sellest nt Tedre 1964b: 53-55). Selgepiirilisemad teoreetilised lähtealused vormelikontseptsioonile töötas välja Udo Kolk: regilaulude praktilisele analüüsile tuginedes eristas ta "stereotüüpse väljenduse" ühe liigina värsisisesed vormelid - s.o värsist väiksemad "vormiliselt samad üksused", mida laulik sai kasutada mitmes erinevas seoses (Kolk 1962). 1960. aastate lääne vormeliteooria (Oral-Formulaic Theory) ja regilaulu vormeliuuringute omavahelisi seoseid selgitab Liina Saarlo (2000: 124-130), arendades neid käsitlusi omavahel põimunult ka edasi (vt nt Saarlo 2001).

4 "Eesti regilaulude andmebaasist" kogu andmebaasi ulatuses tehtud otsingute põhjal (seisuga 11. oktoober 2015) kujunes sõnade esinemisjärg selliselt (võttes aluseks eesti keele põhivärvinimede tüved): must $^{*}-7854$ laulu; valge* -7245 ; hall* -5402 ; puna* 5370 , sini* ${ }^{*}$ 4377; rohe* -259 ; roosa* -375 ; kolla* -199 ; pruun* -25 ; lilla* -82 ; oranž - 0. Sellegipoolest ei näita see reastus üheselt vastava värvinime esinemise sagedust, kuna ei ole selge, kas sõnatüvi viitab otseselt värvile (vt nt paralleeltähendusi valge - päevavalge; must - räpane; otsing hall* toob välja ka hall-halla); võib-olla on tegemist küll värvipilti pakkuva, ent siiski iseseisva mõistega (sinilill) või hoopiski homonüümiga (lilla* -> Naise nimi siirdevormilises laulus "Lilla istus kamberis..."; roosa -> omastav kääne sõnast "roosk", piits), nagu järgmises näites:

Õekesed, ellakesed, neitsikesed, noorukesed,

kirja pihta peenikesed,

lõpetame selle põllu,

vahendame selle väila,

ilma piitsa peksemata,

roosa laia laskemata,

kaikaa karistamata.

H I 1, 250 (134) < Järva-Jaani (1888).

Üldiselt võib "roosat" kohata "roosilise" tähenduses ja väga harva värvi tähenduses, seda riiete kirjelduses ja sageli siirdevormilistes lauludes, nt: "Kui palju lilli näinud ma / ja tuhat karva õied. / Ei need mind nõnda rõõmusta / kui pruudi roosad paelad." H I 4, 578 (4) < (?) (1876). Samuti võib haruharva "lilla" olla värvinimi, nagu nt laulus: “Kübaral on lilla linti, / vöölla vööd ilusad.” E 7910/1 (41) < Ambla (1893). Niisamuti kipub ka "pruun" olema seotud riietusega: "Kust sai kubjas kuue selga, / aidamees sai halli vatti, / kilter Peeter kirju vesti, / Kärnal Mart sai käima kuue, / vahimees sai valged püksid, / mõisa herra musta mantli, / toapoiss sai tuhvlid jalga /mamsel maksa karvalise, / mõisa proua pruuni kleidi? / Kui põleks vaemud vaeva näinud, / teopoisid tööda teinud!” H II 16, 814 (28) < Jüri (1891).

5 Lauluteoreetilise lähtekoha järgi käsitleti "laulu" kui laulutüüpi: laulu kujunemine seoti eeldatava algtekstiga (mida nimetati arhetüübiks), mis eksisteeris variantidena. Stereotüüpsuse uuringute abil oli vaja selgitada variaabluse iseloomu ja ulatust. (Vt nt Laugaste 1962: 26-27; Kolk 1962: 79; Tedre 1964a.)

${ }^{6}$ H III 8, 16 (12) < Kursi (1888); H R 4, 86 (5) < Kursi (1887); H III 9, 178 (15) < Laiuse, 1888). Analoogiliselt võib samas tähenduses olla "punapõlle" ( H II 27, 99 (22) < Kursi (1888); H II 51, 161 (1) < Puhja (1894); H III 21, 260 (2) < Kursi 1894); EÜS VII 2648 (11) < Kambja (1910)).

7 Ingrid Rüütel analüüsib loomisloo (laulutüübid "Loomine", "Siidisulgis linnukene") kujunemisetappe ja toob välja, et varasema ja hilisema versiooni üks tunnuseid on kinnistunud sõnaühendi "sinikirja linnukene" asendumine ühendiga "siidisulgis linnukene". See teisenemine on tingitud muutustest värsimõõdus (vt Rüütel 1969: 109-111). Erinevus seisneb lühikeste pearõhuliste silpide paiknemises värsis: kui 
regilaulus võivad need asetseda kas värsi alguses (kvantiteedireeglite järgi on esimene värsijalg täidetud vabalt) või paarisarvulistes värsipositsioonides (vt nt Sarv 2000: 15), siis siirdevormilise laulu trohheilises värsimõõdus pidid pearõhuline silp ja värsirõhuline positsioon kokku langema. Sellised muutused kajastuvad nimelt ka lühikese pearõhulise silbiga sõna "sini" asendumises II vältelise sõnaga "siidi".

8 Pulmalaul, kus on "sini / puna" samas motiivis: "Kaitse mu õde kalliesti, / sinirinda sirgeeste/, punapõlle puhtakeste.” (H II 2, 179/80 (284) < Karuse (1889); H II 2, 286/7 (415) < Karuse (1889)).

9 Vrd H II 2, 213 (321) < Karuse (1889); EÜS VII 507 (312) < Hanila.

${ }^{10}$ H II 59, 779 (30) < Rõngu (1896).

${ }^{11}$ H II 43, 630 (21) < Laiuse (1887); H IV 4, 436 (9) < Kursi (1988).

${ }^{12}$ H II 43, 635 (32) < Laiuse (1887).

${ }^{13}$ H II 17, 540/1 (26) < Hanila (1889); H II 17, 630/2 (35) < Varbla (1890).

${ }^{14}$ H II 33, 546 (22) < Äksi (1889); ERM 142, 11 (5) < Kursi.

${ }^{15}$ Läänemaa "tuima neiu" motiivis on "nässaka [neiu] nina punane", ent see motiiv, nagu ka värvisõna-ühend ei ole Läänemaal sama levinud kui Tartumaa lauludes. Vrd Tartumaa laule: H II 28, 392 (66) < Maarja-Magdaleena (1888); H II 33, 594 (21) < Sangaste (1890); H III 8, 376 (15) Palamuse (1890); H II 59, 779 (30) < Rõngu < Tarvastu (1896); E 26434 (26) < Otepää (1896); EÜS VII 2656 (26) < Kambja (1910); ERM 148, 8 (10) < Rõngu (1920); ERM 148, 9 (14) < Rõngu (1920); ERM 21, 24 (30) < Rõngu (1920); ERM 21, 29 (41) < Rõngu (1920); E 54112 (16) < Sangaste (1924). ERM 138 (1) < Sangaste (a-ta).

${ }^{16}$ H II 5, 476 (4) < Sangaste (1877).

${ }^{17} \mathrm{H}$ II 28, 392 (66).

18 Tartumaa laulud: H. Ostrov 113 (55) < Laiuse (1887); H II 31, 292 (3) < Otepää (1889); H II 28, 908 (3) < Maarja-Magdaleena (1889); H II 44, 515 (22) < Otepää (1891); H III 8, 865 (16) < Palamuse (1891); H IV, 481 (1) < Rõngu (1891); E 52099 < Palamuse (1892); E 17458 (4) < Rõngu (1895). Läänemaa laulud: E 626, 628 (4) < Pühalepa (1884); EKS 50, 145 (97) < Vigala (1885); H II 2, 157 (260) < Karuse (1889); H II 33, 94 (63) < Karuse (1889); H II 6, 11 (17) < Pühalepa (1890); H II 20, 312 (28) < Vigala (1889); H II 17, 605 (6) < Hanila (1890); vrd uuemas laulus, kus minategelasest noormees ütleb enda kohta: "Olin mina muiste noor ja ilus, / priske, peekjas punane" EÜS II 961 (119) < Reigi (1905).

${ }^{19}$ H II 30, 347 (25) < Rannu (1889); H III 9, 91 (4) < Laiuse (1890); vrd "isamees ilusa / peiupoiss punane": H II 2, 248 (355) < Karuse (1889); E 600087 < Kodavere (1927).

${ }^{20}$ H II 4, $561(28)<$ Kodavere (1887).

${ }^{21}$ H I 5, 513 (1) < Viljandi (1894).

${ }^{22}$ H III 9, 247 (14) < Torma (1888).

${ }^{23}$ Vrd: H II 27, 483 (13) < Palamuse (1889); H II 28, 838 (7) < Maarja-Magdaleena 81890); H III 15, 178 (10) < Palamuse (1891).

${ }^{24}$ H II 30, 149 (6) < Puhja (1889); H II 2, 390 (511) < Karuse (1889); H II 17, 342 (24) < Vigala (1889); E 51147 < Lääne-Nigula (1920); E 68906 < Varbla 81930); E 69978 $<$ Karuse (1930); E $78427<$ Ridala (1931).

${ }^{25}$ H III 7, 181 (17) < Sangaste (1889). 
${ }^{26}$ Tartumaa, peamiselt Maarja-Magdaleena khk: H II 28, 59 (24) < Maarja-Magdaleena (1888); H II 28, 711 (1) < Maarja-Magdaleena (1889); E A 189 81) < Maarja-Magdaleena (1892); H II 56, 571 (7) < Maarja-Magdaleena (1895); ERM 85, $1<$ Kursi (1920); Läänemaa: E A $53(90,91)<$ Vigala (1889); H II 17, 465 (90) < Vigala (1889); H II 2, $352(478)<$ Karuse (1889).

${ }^{27}$ H III 10, 588 (3) < Sangaste (1889).

${ }^{28}$ H II 27, 566 (6) < Palamuse (1888).

${ }^{29}$ Vt nt E 17458 (4) < Rõngu (1895); H II 28, 908 (3) < Maarja-Magdaleena(1891); H II 17, 605 (6) < Hanila (1889).

${ }^{30}$ Vrd: Tartumaal: H II 28, 63 (4) < Maarja-Magdaleena (1888); H II 50, 610 (9) < Kodavere (1891); H II 50, 765 (51) < Äksi (1894); H II 56, 433 (129) < Maarja-Magdaleena (1895); H II 56, 594 (4) < Maarja-Magdaleena (1895); E 18319 (7) < Äksi (1895); EÜS II 376 (105) < Kodavere (1905); Läänemaal: H II 2, 29 (48) < Märjamaa (1889); H II 2, 279 (403) < Karuse (1889); H II 2, 646 (801) < Varbla (1889); H II 47, 243 (14) $<$ Karuse (1894); H III 23, 698 (13) < Vigala (1895).

${ }^{31}$ H III 9, 467 (2) < Tartu-Maarja (1888); E $52257<$ Palamuse (1892); EKS 39, 9 (18) $<$ Rannu (1900); EÜS II 308 (9) < Kodavere (1905).

${ }^{32}$ H II 2, 479 (632) < Hanila (1889).

${ }^{33}$ H II 2, 300 (431) < Karuse (1889); H IV 2, 63 (15) < Karuse (1889).

${ }^{34}$ Vrd H III 29, 181 (5) < Vigala (1898) ja Tartumaa lauludes: H II 4, 644 (10) < Kodavere (1887); H, Ostrov 154 (42) < Torma (1887); H III 9, 177 (11) < Laiuse (1888); H III 9, 529 (6) < Tartu-Maarja (1889); H II 30, 193 (15) < Puhja (1889); H II 44, 529 (51) < Otepää (1891); H III 8, 860 (10) < Palamuse (1891); E 52049 < Palamuse (1892); E $18318<$ Äksi (1895); E 22610 (5) < Torma (1896); EÜS V 1104 (99) < Laiuse (1908); EÜS VI 830 (92) < Puhja (1909); EÜS VII 2681 (5) < Rannu (1910); EÜS VIII 1163 (28) < Laiuse (1911); E 64741 (6) < Torma (1930).

${ }^{35}$ Vrd: H II 17, 435 (32) < Vigala (1889).

${ }^{36}$ H II 56, 549 (5) < Tartu-Maarja (1895). Vrd: H II 31, 831 (12) < Sangaste (1889); H II 44, 335 (2) < Otepää (1891); H II 44, 542 (38) < Otepää (1891); H III 22, 69 (16) < Otepää (1895); H II 59, 795 (37) < Sangaste (1898); ERM 85, 2 < Kursi (1920).

${ }^{37}$ H III 10, 593 (9) < Sangaste (1889).

${ }^{38}$ Vt nt H II 31, 599 (53) < Otepää (1890).

${ }^{39}$ Vt võrdlevalt skeemi puna- ja verevä-ühendite kohta artikli kommentaaride lõpust.

${ }^{40}$ Vt nt EÜS VII 506 (311) < Hanila (1896).

${ }^{41}$ Tartumaa "pilves veepisarad" motiivi sisaldavas kaheksast tekstist esineb ühes tavatu seos (hani ei ole mitte punane, vaid sinine ja saba vastavalt punane) ja värvijärg ("sinine / punane"): EÜS II 376 (105) < Kodavere (1905). Ülejäänud seitsmes Tartumaa ja viies Läänemaa laulutekstis on sama sõnastus: hani punane / saba sinine. Tartumaa laulikute võistusõnad vt nt "ole vait, täna su suu punane” E $18318<$ Äksi (1895).

42 EÜS X 596 (51) < Martna (1913). 


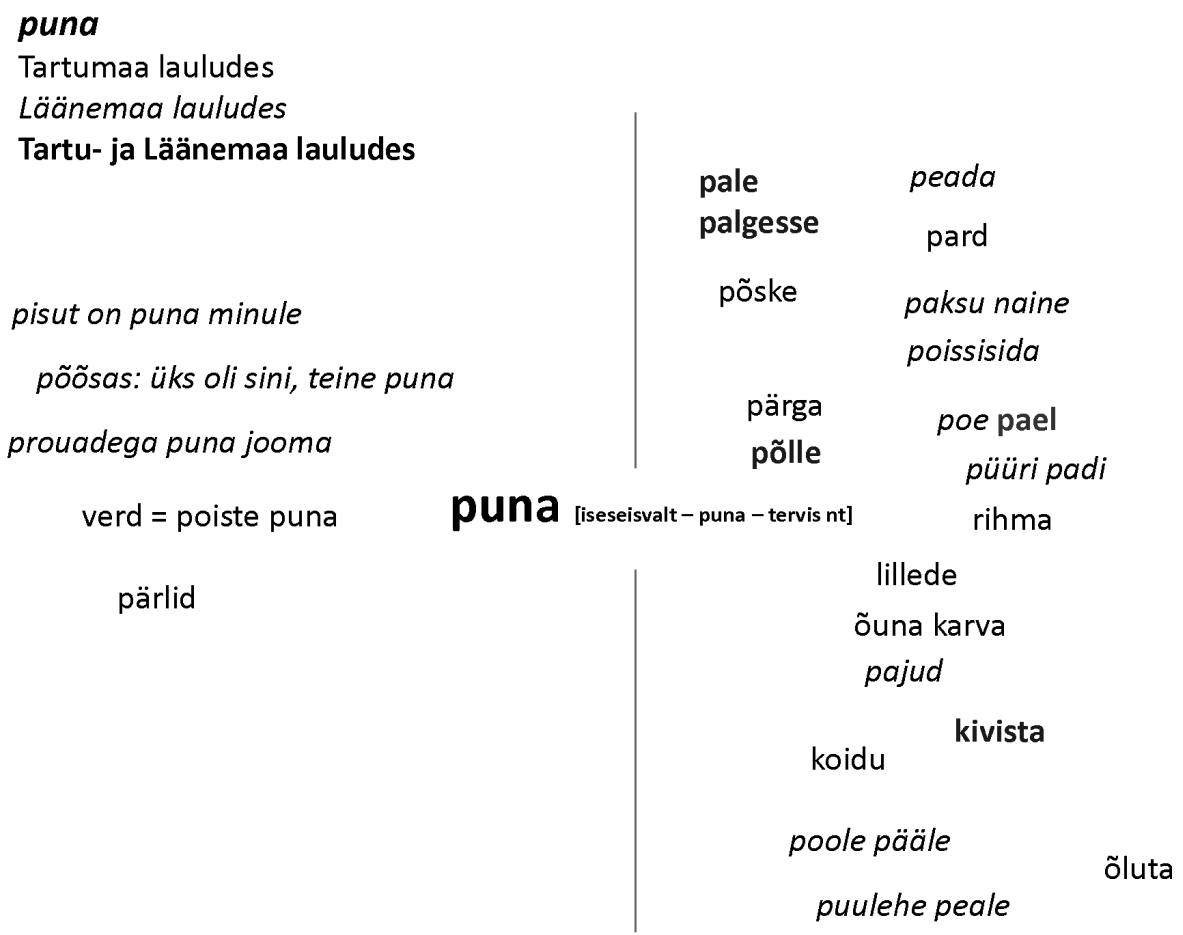

Skeem 2. Puna esinemine Tartu- ja Läänemaa lauludes.

verevä Tartumaa lauludes

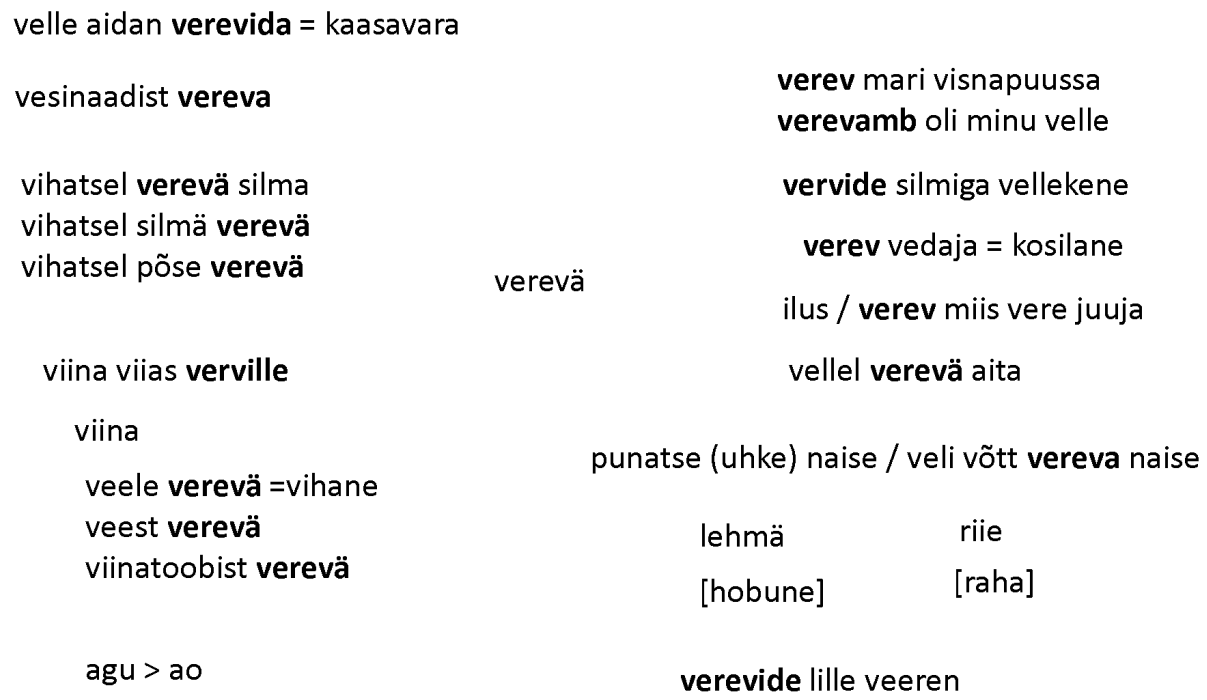

Skeem 3. Verevä esinemine Tartumaa lauludes. 


\section{Kasutatud allikad}

E-andmebaas (Eesti Rahvaluule Arhiiv, Eesti Kirjandusmuuseum)

Eesti regilaulude andmebaas, http://www.folklore.ee/regilaul/andmebaas

$\mathrm{H}$ - Jakob Hurda rahvaluulekogu (1860-1906)

E - Matthias Johann Eiseni rahvaluulekogu (1880-1934)

EÜS - Eesti Üliõpilaste Seltsi rahvaluulekogu (1875-1917)

ERM - Eesti Rahva Muuseumi rahvaluulekogu (1872-1924)

\section{Kirjandus}

Allik, Jüri 1982. Värvitaju, värvinimetused ja värvisümboolika. Looming 3, lk 378-384.

Ben-Amos, Dan 2009a [1971]. Folkloori defineerimine konteksti kaudu. Dan Ben-Amos. Kommunikatsioon ja folkloor. Sator 9. Tartu: EKM Teaduskirjastus \& Eesti Folkloori Instituut, lk 9-26 (http://www.folklore.ee/rl/pubte/ee/sator/sator9/ - 26. aprill 2016).

Ben-Amos, Dan 2009b [1993]. 'Kontekst' kontekstis. Dan Ben-Amos. Kommunikatsioon ja folkloor. Sator 9. Tartu: EKM Teaduskirjastus \& Eesti Folkloori Instituut, lk 27-45 (http://www.folklore.ee/rl/pubte/ee/sator/sator9/ - 26. aprill 2016).

Eesti rahvalaulud 1926 = Eisen, Matthias Johann \& Krohn, Kaarle Leopold \& Alava, Vihtori \& Kallas, Oskar \& Anderson, Walter \& Ridala, Villem (toim). Eesti rahvalaulud Dr. Jakob Hurda ja teiste kogudest I. Tartu: Eesti Kirjanduse Selts.

Ernits, Enn \& Sarv, Mikk \& Tedre, Ülo \& Kõiv, Madis \& Lõugas, Vello \& Vint, Tõnis \& Viires, Ants \& Stöör, Ülo \& Eelsalu, Heino 1981. Värvid, arvud, kujundid. Esivanemate maailmapildist. Looming 11, lk 1600-1608. Kordustrükk: Mäetagused 61, 2015, lk 69-80 (http://www.folklore.ee/tagused/nr61/pilt.pdf, doi: 10.7592/MT2015.61.pilt).

Harvilahti, Lauri 1992. Kertovan runon keinot. Inkeriläisen runoeepiikan tuottamisesta. Helsinki: Suomalaisen Kirjallisuuden Seura.

Jaago, Tiiu 1997. Mis sealt tõuseb, soost sinine, soost sinine, maast punane? Sinise ja punase võimalikust tähendusest regilaulus. Mäetagused 5, lk 54-72 (http://www.folklore. ee/tagused/nr5/pdf/tiiu.pdf, doi:10.7592/MT1997.05.tiiu).

Jaago, Tiiu 2013. Linnateema vanemas rahvalaulus. Keel ja Kirjandus 7, lk 490-506 (http://kjk.eki.ee/ee/issues/2013/7/416 - 26. aprill 2016).

Kolk, Udo 1962. Värsisisesed vormelid eesti regivärsilises rahvalaulus. Töid filoloogia alalt I. Tartu Riikliku Ülikooli toimetised 117. Tartu: TRÜ Kirjastus, lk 71-153.

Kolk, Udo 1980. Regivärsi stereotüüpiast. Eesti rahvaluule žanriprobleemid. Tartu Riikliku Ülikooli toimetised 528. Tartu: TRÜ Kirjastus, lk 25-48.

Laugaste, Eduard 1962. Eesti regivärsi struktuuriküsimusi. Värsisisesed vormelid eesti regivärsilises rahvalaulus. Töid filoloogia alalt I. Tartu Riikliku Ülikooli toimetised 117. Tartu: TRÜ Kirjastus, lk 25-67.

Parmasto, Erast 1982. Mitmevärviline maailm. Looming 3, lk 375-377. 
Peegel, Juhan 1997 [1969]. Nimisõna poeetilisest sünonüümikast eesti regivärssides. Juhan Peegel. Kuld on jäänud jälgedesse. Regivärsi keelest ja poeetikast. Tartu: Eesti Kirjandusmuuseum, lk 49-61.

Peegel, Juhan 1997 [1972]. Sõnaseoseid jälgides. Juhan Peegel. Kuld on jäänud jälgedesse. Regivärsi keelest ja poeetikast. Tartu: Eesti Kirjandusmuuseum, lk 102-116.

Peegel, Juhan 2004. Nimisõna poeetilised sünonüümid eesti regivärssides. Teine läbivaadatud ja ühtlustatud trükk. Tallinn: Eesti Keele Sihtasutus.

Rammo, Riina 2015. Sinine, punane, valge. Tutulus. Eesti Arheoloogia Ajakiri 2015, lk 44-46.

Roll, Tiiu 1985. Värvinimetused ja nende kujundiline osa regivärsilises pulmalaulus. Tartu Riikliku Ülikooli toimetised 669. Tartu: Tartu Riiklik Ülikool, lk 34-56.

Rüütel, Ingrid 1969. Muistne "Loomislaul” eesti uuemas rahvatraditsioonis. Paar sammukest eesti kirjanduse uurimise teed VI. Tallinn: Eesti Raamat, lk 102-132.

Rüütel, Ingrid 1971. Eesti uuema rahvalaulu varasemast arengujärgust. Paar sammukest eesti kirjanduse uurimise teed VII. Tallinn: Eesti Raamat, lk 11-100.

Saarlo, Liina 2000. Kodavere regilaulude vormelid. Jaago, Tiiu \& Ülo Valk (toim). Kust tulid lood minule... Artikleid regilaulu uurimise alalt 1990. aastatel. Tartu: Tartu Ülikooli Kirjastus, lk 123-160.

Saarlo, Liina 2001. Regilaulude vormelid: kvantiteet ja kvaliteet. Jaago, Tiiu \& Sarv, Mari (toim). Regilaul - keel, muusika, poeetika. Tartu: Eesti Kirjandusmuuseum. Eesti Rahvaluule Arhiiv \& Tartu Ülikool. Eesti ja võrdleva rahvaluule õppetool, lk 271-297.

Sarapik, Virve 1993. Vikerkaar, värv ja teadusmütoloogia. Kõiva, Mare (toim). Eksperimentaalne folkloristika. Tallinn: Keele ja Kirjanduse Instituut, lk 49-59.

Sarapik, Virve 1994. Valge ja must. Keel ja Kirjandus 11, lk 641-649; 12, lk 713-717.

Sarapik, Virve 1997. Red: the Colour and the Word. Folklore, EJF 3, lk 93-130 (http:// www.folklore.ee/folklore/vol3/pdf/red.pdf, doi:10.7592/FEJF1997.03.red).

Sarv, Mari 2000. Regilaul kui poeetiline süsteem. Oras, Jaanika \& Västrik, Ergo-Hart (toim). Paar sammukest XVII. Eesti Kirjandusmuuseumi aastaraamat. Tartu: Eesti Kirjandusmuuseum.

Sarv, Mikk \& Sarv, Tõnn 1979. Loomise lugu. Eesti Loodus 7, lk 449-452.

Sutrop, Urmas 1995. Eesti keele põhivärvinimed. Keel ja Kirjandus 12, lk 797-808.

Sutrop, Urmas 1996. Eesti keele värvussõnavara arengu põhijooni. Keel ja Kirjandus 10, lk 661-674.

Tedre, Ülo 1964a. Tähelepanekuid regivärsilise rahvalaulu tüpoloogiast. Pino, Veera \& Tedre, Ülo \& Viidalepp, Richard (toim). Eesti rahvaluulest. Tallinn: Keele ja Kirjanduse Instituut, lk 7-34.

Tedre, Ülo 1964b. Stereotüüpsusest Karksi rahvalauludes. Pino, Veera \& Tedre, Ülo \& Viidalepp, Richard (toim). Eesti rahvaluulest. Tallinn: Keele ja Kirjanduse Instituut, lk 52-84.

Tuglas, Friedebert 1912. Kirjanduslik stiil. Mõned leheküljed salmi ja proosa ajaloost. Noor-Eesti IV [album]. Tartu: E.K.S. Noor-Eesti, lk 23-100. 
Uusküla, Mari 2008. Eestlasele punane, soomlasele punakas: värviprototüüpidest erinevates keeltes. Oma Keel 2, lk 13-21 (http://www.emakeeleselts.ee/omakeel/2008_2/ OK_2008-2_02.pdf - 27. aprill 2016).

Uusküla, Mari \& Sutrop, Urmas 2014. Põhivärvinimed Läänemere ümbruse keeltes: areaalsed, universaalsed või relativistlikud. Keel ja Kirjandus 8-9, lk 670-683 (http:// kjk.eki.ee/ee/issues/2014/8-9/539 - 28. aprill 2016).

Viires, Ants 1983. Eestlaste värvimaailmast. Keel ja Kirjandus 6, lk 290-302.

\section{Summary}

\section{'Red': Colour term and formulaic poetic language}

\section{Tiiu Jaago}

Keywords: colour terms, Estonian old folk song regilaul, formula, red

In this article the occurrence of the colour term 'red' is studied comparatively in the regilaul of two Estonian counties. Earlier studies on colour terms in the Estonian regilaul have shown that colour terms are rarely found in songs. At the same time, they are conspicuous in set phrases, forming formulae, fixed lexical combinations characteristic of the regilaul tradition.

The analysis of the songs studied in this article is based on the formulaic concept (i.e. the premise that colour terms are found in set lexical phrases). In interpreting colour term-containing motifs and related topics, this article draws on context-centred folklore research (i.e. the premise that the meaning of neither the formulae nor the colour terms is autonomous, independent of their context of use).

A formula containing a colour term does not carry an unambiguous meaning. It is not possible to say, for example, what evaluation the modifier 'red' involves in such compounds as 'pale punane' (red countenance), 'punane põosas' (red bush), 'proua punane' (red lady). However, it reveals that on the motif level these formulae carry a certain meaning: in the praise of the bride or the groom in wedding songs, the 'pale punane' (red countenance) refers to health and youth, while in the 'indifferent maiden' motif it refers to the angry disposition of the maiden. Partly, the meanings of 'red' become evident thanks to its parallel words (ilus / punane - handsome / red), while on the motif level it appears when the word is used to praise or warn against a character (ilus mees on ihusöoja - punane aga verejooja (the handsome husband is a flesh-eater, the red one a blood-drinker): such a young man is not recommended to the girl, as working in the man's house would ruin her health).

It is characteristic that 'red' tends to be related with the topic of courting and wedding. When the parallel word of 'red' is 'blue' (e.g. Minu hella emakene, / siruta see sinine lõnga, / poeta punane paela, / tõmba minu taevasse (Dear mother, / stretch out the blue yarn, / drop down the red ribbon, / pull me up to the heaven)), it remarkably often describes a border situation, either in the social (wedding, death) or natural environment (morning, evening).

In summary, it can be said that lexical phrases or formulae that contain colour terms can vary widely. However, the thematic context of using formulae that contain colour terms is considerably stable. 